\title{
A COMPARATIVE VIEW OF EQUALITY UNDER THE UN CONVENTION ON THE RIGHTS OF PERSONS WITH DISABILITIES AND THE DISABILITY LAWS OF THE UNITED STATES AND CANADA
}

\author{
Arlene S. Kanter*
}

In 2006, the United Nations adopted the Convention on the Rights of Persons with Disabilities [CRPD], the first international treaty addressing specifically the rights of people with disabilities, including in the workplace. The purpose of the CRPD is "to promote, protect and ensure the full and equal enjoyment of all human rights and fundamental freedoms by all persons with disabilities, and to promote respect for their inherent dignity...." The CRPD has been ratified by 160 countries, including Canada, but not yet by the United States. Article 27 of the CRPD, entitled Work and Employment, prohibits not only discrimination against people with disabilities in employment, but also the right of people with disabilities to reasonable accommodations, equal remuneration for work of equal value, safe and healthy working conditions, assistance in finding, obtaining, maintaining and returning to employment, rehabilitation, job retention and return-to-work programmes, as well as affirmative action programmes, incentives and other measures to promote equal employment opportunities. As compared to the Americans with Disabilities Act and the Canadian Charter, the CRPD, therefore, goes beyond prohibiting discrimination and instead seeks to ensure greater substantive equality for people with disabilities in the workplace. As such, the author proposes that both US and Canadian legislatures and courts should look to the CRPD to help their respective countries move beyond traditional notions of formal equality towards a new right to substantive equality in the workplace for people with disabilities.

En 2006, les Nations Unies ont adopté la Convention relative aux droits des personnes handicapées [CDPH], le premier traité international portant explicitement sur les droits des personnes handicapées, y compris les droits dans le milieu de travail. La CDPH a pour objet de " promouvoir, protéger et assurer la pleine et égale jouissance de tous les droits de l'homme et de toutes les libertés fondamentales par les personnes handicapées et de promouvoir le respect de leur dignité intrinsèque [...] ». La CDPH a été ratifiée par 160 pays, dont le Canada, mais les États-Unis ne l'ont pas encore ratifiée. En plus d'interdire la discrimination fondée sur le handicap dans tout ce qui a trait à l'emploi, l'article 27 de la CDPH, intitulé "Travail et emploi », protège le droit des personnes handicapées de bénéficier d'aménagements raisonnables, de l'égalité de rémunération à travail égal ainsi que de la sécurité et de l'hygiène sur les lieux de travail, le droit d'obtenir de l'aide liée à la recherche et à l'obtention d'un emploi, au maintien dans l'emploi et au retour à l'emploi, l'accès à des 
programmes de réadaptation, de maintien dans l'emploi, de retour à l'emploi et d'action positive, de même que l'accès à des incitations et à d'autres mesures visant à promouvoir l'égalité des chances dans l'emploi. En conséquence, comparativement à l'Americans with Disabilities Act et à la Charte canadienne, la CDPH va plus loin qu'interdire la discrimination et vise à assurer une plus grande égalité réelle pour les personnes handicapées dans le milieu de travail. $C$ 'est pourquoi l'auteur propose que les assemblées législatives et les tribunaux des États-Unis et du Canada examinent la CDPH afin d'aider les instances décisionnelles de leurs pays respectifs à dépasser les notions traditionnelles de l'égalité formelle et à promouvoir un nouveau droit à l'égalité réelle dans le milieu de travail pour les personnes handicapées.

\section{INTRODUCTION}

People with disabilities are subjected to discrimination in most, if not all, countries throughout the world, despite national laws specifically adopted to prohibit such discrimination. These national laws differ in their scope and coverage, but most seek to end the discrimination that people with disabilities experience in accessing employment, education, buildings, public services and accommodations. ${ }^{1}$ In addition to national laws, the United Nations [UN] itself adopted the first international treaty on the rights of people with disabilities in 2006. This treaty, the Convention on the Rights of Persons with Disabilities [CRPD], has been ratified by 163 countries, including Canada, but not yet by the United States. It was drafted specifically to go beyond merely prohibiting discrimination to address the right of people with disabilities to equality. ${ }^{2}$

In this Article, I compare the right to equality for people with disabilities under the CRPD, the Americans with Disabilities Act [ADA] and the Canadian Charter of Rights and Freedoms, ${ }^{3}$ focusing primarily on employment rights. The first section of the Article discusses the meaning and application of the right to equality for people with disabilities, followed by the CRPD's view of equality. The next two sections of the article discuss, respectively, U.S. and Canadian court decisions which address the extent to which people with disabilities are treated equally in employment settings under their domestic laws. Based on this comparative analysis, I argue that the CRPD has a more extensive view of equality than contained in either U.S. or Canadian law. For that reason, I conclude this article by arguing that both U.S. and Canadian legislatures and

* Bond, Schoeneck \& King Distinguished Professor of Law; Laura J and L Douglas Meredith Professor of Teaching Excellence, Director, Disability Law and Policy Program, Co-Director, Center on Human Policy, Law, and Disability Studies, Syracuse University College of Law. I wish to thank Daniel Van Sant (SUCOL'16) for his research assistance on this article.

1 Arlene S Kanter, "The Globalization of Disability Rights Law" (2003) 30 Syracuse J Intl L \& Com 241.

2 See online: United Nations $<$ https://www.un.org/development/desa/disabilities/>. For a comprehensive analysis of the CRPD, including an overview of the history of its drafting process and its implications for people with and without disabilities under international human rights law, see Arlene S Kanter, The Development of Disability Rights under International Law: From Charity to Human Rights (New York: Routledge Press, 2015).

3 Canadian Charter of Rights and Freedoms, s 15(1), Part I of the Constitution Act, 1982, being Schedule B to the Canada Act 1982 (UK), 1982, c 11; 
courts may learn from the drafting process and language of the CRPD, even in the absence of its ratification, as in the case of the United States. It is the CRPD's vision of equality for people with disabilities that moves beyond traditional notions of formal equality and equality of opportunities (as contained in U.S. law) towards an affirmation of a new right to substantive equality including in the workplace for people with disabilities.

\section{EQUALITY AND PEOPLE WITH DISABILITIES}

Equality is one of the foundational principles that guide our actions, laws, and judicial decision-making. Yet the concept of equality is complex and contested. Equality, as a concept, may require that everyone be treated exactly the same; or, it may mean that people should be treated differently in order to achieve the same or "equal" result. As the Canadian Disability Studies scholar, Marcia Rioux, has written, "the infuriatingly elusive concept of equality encompasses an elastic spread of meanings that range from legitimizing and formalizing differences and unequal treatment, to incorporating broad environmental and institutional changes, services, policies and programs to ensure equality is achieved." ${ }^{4}$ In this section, I will explain three models of equality and their application to people with disabilities. These models are: formal equality, equality of opportunities, and substantive equality or equality of results or outcome.

\section{A. Formal Equality}

The notion of formal equality that Aristotle formulated in reference to Plato requires that like cases be treated alike. ${ }^{5}$ This model, sometimes referred to as the "sameness model," assumes that every individual must be treated the same, regardless of the presence or absence of individual differences. Under this model, society's rights and benefits are distributed according to each person's merit; inequalities in wealth, education, power or abilities remain unchallenged. All people are seen as free to make their own choices and to carry out those choices, so long as the state does not interfere. ${ }^{6}$ Accordingly, a formal view of equality is attractive to state actors

4 Marcia H Rioux, Lee Ann Basser \& Melinda Jones, eds, Critical Perspectives on Human Rights and Disability

Law (Boston: Martinus Nijhoff Publishers, 2011) at 241. In addition to the chapter by Marcia Rioux and Christopher Riddle, entitled Values in Disability Policy and Law: Equality Critical Perspectives at 37, other scholars have discussed the three main normative theories of equality in relation to people with disabilities, from whom I draw my analysis. See Gerard Quinn et al, "Human Rights and Disability: The Current Use and Future Potential of United Nations Human Rights Instruments in the Context of Disability", online: (2002) National Human Rights Institutions Forum < http://www.nhri.net/pdf/disability.pdf > at 2, 16-18; Arlene Mayerson \& Silvia Yee, "The $A D A$ and Models of Equality", online: Disability Rights Education \& Defense Fund $<$ http://dredf.org/news/publications/disability-rights-law-and-policy/the- $A D A$-and-models-of-equality/> (in the context of the $A D A$ ); Anita Silvers, David Wasserman \& Mary B Mahowald, Disability, Difference, Discrimination: Perspectives on Justice in Bioethics and Public Policy (New York: Rowman \& Littlefield Publishers, 1998).

5 Aristotle, Nicomachean Ethics, vol 3, 1131a10-b15; Aristotle, Politics (Athens: Papyrus, 1975) III.9.1280 a815, III. 12. 1282b18-23.

6 Ibid. See a contemporary view of this model in Robert Nozick, Anarchy, State, and Utopia (New York: Basic Books, 1974). 
because the state's only role under this model of equality is to prohibit the less favorable treatment of individuals who are similarly situated. Thus discrimination would occur only when an individual with similar qualifications is treated differently. In the context of employment, formal equality would demand that an employer consider only a job applicant's "merit," but not other factors such as the applicant's race, national origin, gender, religion, age, education, family background, wealth that may relate to the applicant's qualifications, position of entitlement or ability to do the job. ${ }^{7}$

This "sameness" approach of the formal equality model therefore ignores entirely the fact that some people may be hired for reasons other than merit. It also ignores the fact that other people may experience disadvantages based on factors also unrelated to merit. Thus formal equality may prohibit intentional discrimination, but it fails to eradicate actions that have a discriminatory impact on a particular group. ${ }^{8}$

The limitations of formal equality for people with disabilities, in particular, should be obvious. Simply treating all people the same will not guarantee equality for those people with disabilities who may need accommodations or modifications at their workplace. Although not all people with disabilities need accommodations, some people with disabilities do; for them, the structures, policies, and workplaces themselves may need to be changed in order for workers with disabilities to be treated like "everyone else" without disabilities. ' For people with disabilities, formal equality is not always enough. ${ }^{10}$ Although formal equality may be codified by law, a qualified person with a disability will nonetheless face discrimination in hiring and promotion unless the workplace is actually made accessible - unless written materials are available in alternate formats for employees who are blind, unless communication access is guaranteed for people who are Deaf or hard of hearing, and unless the physical building is accessible for people with mobility impairment. As Marcia Rioux, again has observed, formal equality "is not sufficiently attuned to the concrete needs of those who are in fact "different" or who are not similarly situated." 11

7 Judging "merit," however, is not an objective exercise. What is and is not considered merit involves subjective judgments and reflects potentially differing values. See e.g. Grutter v Bollinger, 539 US 306 at $337-39$ (2003). In Grutter, the United States Supreme Court upheld the affirmative action admissions policy of the University of Michigan Law School. The Court held that the University of Michigan Law School had a compelling interest in promoting class diversity and that its race-conscious admissions process that favored "underrepresented minority groups" but also took into account other factors related to the merit of each individual applicant, did not amount to a quota system that would have been unconstitutional under Regents of the University of California v Bakke, 438 US 265 (1978).

$8 \quad$ Rioux et al, supra note 4 at 44.

9 People with disabilities are themselves a diverse group of people with different needs, abilities, skills, and life preferences. Many people with disabilities require no accommodations or modifications, yet others do. See Arlene S Kanter, "The Law: What's Disability Studies Got to Do with It or An Introduction to Disability Legal Studies" (2011) 42:2 Colum HRLR 403 at 435-36.

10 Rioux et al, supra note 4 at $42-44$.

11 Ibid. Marcia Rioux has observed that the formal equality approach to disability places its emphasis on "the tragedy of being disabled and individuals are viewed as anomalies albeit worthy of society's charity and benevolence. Disability is viewed as a natural occurrence and luck based, emphasizing the requirement of a private and not societal approach to addressing disability." See also Quinn et al, supra note 4 at 2. 


\section{B. Equality of Opportunities}

In response to the limits of formal equality, an alternative model of equality has emerged, known as equality of opportunities. ${ }^{12}$ This model of equality does not rely on a person's individual characteristics or good fortune. Instead, this model of equality supports the view that all people will be treated equally once we remove the barriers that prevent people - for whatever reason - from participating equally in society. ${ }^{13}$ One of the main premises of this view of equality is that all people have "something to contribute to humanity and that social structures should be built inclusively with human empowerment as a key goal.",14

The right to equality of opportunities has long been recognized as an appropriate model with which to advance the rights of people with disabilities. ${ }^{15}$ This model takes into account the historical conditions of inequality as well as present day environmental, physical, communication, legal, and attitudinal barriers. ${ }^{16}$ Further, because this model addresses some of the "persistent effects of discrimination," ${ }^{, 17}$ it is considered a vast improvement over a formal view of equality. ${ }^{18}$ Indeed, equality of opportunities is the model of equality upon which civil rights laws are based, including the Americans with Disabilities Act, the Canadian Human Rights Act, and, to a lesser extent, the United Nations Convention on the Rights of Persons with Disabilities. ${ }^{19}$

Within the field of international law, the first document to incorporate the equality of opportunities model for people with disabilities is the 1975 Declaration on the Rights of Disabled People. ${ }^{20}$ This document refers to equality as "the process through which the general system of society, such as the physical and cultural environment, housing and transportation, health services, education, and employment, social life, include sports and secretariat facilities are made

12 See e.g. Equal Opportunities for Individuals with Disabilities, 42 USCS $§ 12101(A)(7)$ (2008) (discussing "the Nation's proper goals regarding individuals with disabilities are to assure equality of opportunity, full participation, independent living, and economic self-sufficiency for such individuals;" 20 USCS § 1400(C)(1) (discussing how "[i]mproving educational results for children with disabilities is an essential element of our national policy of ensuring equality of opportunity, full participation, independent living, and economic selfsufficiency for individuals with disabilities;" NY CLS Const Art VI, § 62 (noting that "the equal protection of the laws means equality of opportunity to all in like circumstances, and classification to be valid must not be arbitrary and discriminate against persons without a basic reason."

13 Rioux et al, supra note 4 at 44.

14 Quinn et al, supra note 4 at 2.

15 Equal Opportunities for Individuals with Disabilities, supra note 11 (discussing "the Nation's proper goals regarding individuals with disabilities are to assure equality of opportunity, full participation, independent living, and economic self-sufficiency for such individuals.")

16 Rioux et al, supra note 4 at 44.

17 Ibid at 45.

18 Ibid.

19 See Americans with Disabilities Act of 1990, Pub L No 101-336, 104 Stat 327 (codified as amended at 42 USC $\S 12101$ et seq (2010)) [ADA]; Canadian Human Rights Act, RSC 1985, c H-6; Convention on the Rights of Persons with Disabilities, 13 December 2006, A/RES/61/106, online: United Nations Enable $<$ https://www.un.org/development/desa/disabilities/convention-on-the-rights-of-persons-withdisabilities/convention-on-the-rights-of-persons-with-disabilities-2.html > [CPRD].

20 Declaration on the Rights of Disabled Persons, GA Res 3447 (XXX), 30 UNGAOR, 13th Sess, Supp No 34, UN Doc A/10034 (1975) at 88. 
accessible to all." 21 It also affirms the right to accommodations, modifications, services and support. But the Declaration on the Rights of Disabled People, like all of the other subsequent international documents that were adopted prior to the CRPD, ${ }^{22}$ falls short of affirming unequivocally the right of all people with disabilities to substantive equality as a matter of international law. ${ }^{23}$ Caveats and conditions in these international documents are attached to the right of people with disabilities to equal opportunities so that accommodations and modifications may be required, but only so long as they are "reasonable" and create no "undue" burden or hardship. $^{24}$ These exceptions to the right to equality of opportunities are also contained in U.S. laws and some Canadian judicial decisions, as discussed below.

Moreover, the preference for the equal opportunities model has been called into question by contemporary scholars who argue that this model does not go far enough to ensure equality for people with disabilities. ${ }^{25}$ These scholars concede that while ensuring equality of opportunities, particularly on a case by case basis, may provide "equal" access to a building or some accommodations on the job, it does not address the underlying causes of different treatment, particularly to the extent that such causes may relate to power or privilege within any given society. ${ }^{26}$ Further, this model does not acknowledge that some people with disabilities may be denied accommodations altogether, or that other people with disabilities may not be able to request accommodations in the first place (because they don't know how), or that others may choose not to receive any accommodations or modifications even if they are offered. In these cases, even the right to "equality of opportunities," will not change a society that allows for "social marginalization and devaluation" of people with disabilities. ${ }^{27}$

Another problem with the equality of opportunities model is that it runs the risk of fostering a negative image of people with disabilities within society at large. Disability Studies scholar, Lennard Davis, has observed that a model of equality that is based on providing "special" services or accommodations may invoke a negative image of a person with a disability who chooses to sue his or her employer. ${ }^{28}$ Davis has therefore argued that when "special" treatment is required in the employment context... people with disabilities are seen as "overly self-concerned, overly demanding.... [and] regarded as narcissists... [and] as demanding exceptions for themselves that

21 Ibid.

22 See e.g. Principles for the Protection of Persons with Mental Illness and for the Improvement of Mental Health Care, OHCHR, 1991, UN Doc A/RES/46/119; Standard Rules on the Equalization of Opportunities for Persons with Disabilities, Res 48/96, 1993, UN Doc A/RES/48/96.

23 Kanter, supra note 2 at 6.

24 See $A D A$, supra note 19.

25 See Arlene S Kanter, The Americans with Disabilities Act at 25 Years: Lessons to Learn from the UN Convention on the Rights of People with Disabilities, 63 DRAKE L.R. 819, 842 (2015); Rioux et al, supra note 4 at 241; Janet E Lord \& Rebecca Brown, "The Role of Reasonable Accommodation in Securing Substantive Equality for Persons with Disabilities: The UN Convention on the Rights of Persons with Disabilities" in Rioux et al, supra note 4 at 273-307.

26 See, e.g. Beth Ribet, "Emergent Disability and the Limits of Equality: A Critical Reading of the UN Convention on the Rights of Persons with Disabilities" (2011) 14 Yale Human Rts \& Dev LJ 101 at 105.

27 Ibid.

28 Lennard J Davis, “Bending over Backwards: Disability, Narcissism, and the Law” (2000) 21:1 Berkeley J Emp \& Lab L 193 at 197. 
overstep what employers can or should provide." 29 Although Davis and others can cite to extensive research that counters this view, as long as this negative view of people with disabilities, as a group, remains unchallengeable through law, people with disabilities will remain stigmatized and considered unemployable.

\section{Substantive Equality or Equality of Results or Outcomes}

In contrast to the equality of opportunities model, the concept of "substantive equality" does not focus only on the need for accommodations in order to ensure equal treatment. Rather, the focus of substantive equality is on the result or outcome of equal treatment. According to this model, the result of societal actions must be equal; but the way in which such equality may be achieved need not be equal. In other words, a model that focuses on "equality of results" differs dramatically from formal equality because it assumes not only that each individual possesses different traits or abilities but also that in order to provide equality for all, such differences must be identified and taken into account - even in the form of preferential treatment, if necessary. ${ }^{30}$ According to this model, the result must be equal, while the means for achieving the result may be different, and may include preferential or special treatment, affirmative action, accommodations and other modifications. In short, substantive equality actually demands unequal or different treatment for those people who may or may not be equally situated. ${ }^{31}$ This model therefore recognizes the limits of legal justifications for different treatment and acknowledges that inequitable treatment, discrimination, and inequality itself are not the individual's doing but rather the result of state action and long-held societal views. As a result, substantive equality has found

29 Ibid.

30 Most of the scholarly attention to "difference" analysis has come from feminist theorists, who have "generated two leading schools of thought regarding the courts' approaches to biological differences." One school of thought discusses an 'equal treatment model' that portrays equality as a requirement that similarly situated persons should be treated alike. The second school of thought criticizes the first model for granting women equality only when they are similarly situated to men. This second model also has been criticized for relegating women to separate spheres such as those created by "protective legislation" that hampers women's employment opportunities. See e.g. Mary Ellen Maatman, "Listening to Deaf Culture: A Reconceptualization of Difference Analysis under Title VII" (1996) 13:2 Hofstra Lab \& Empl LJ 269.

31 Recently, the Supreme Court of Canada explained that equality is not about sameness. Withler v CanADA, 2011 SCC 12 at para 60, [2011] 1 SCR 396. Section 15(1) of the Charter "protects every person's equal right to be free from discrimination." (Withler at para 31). The Court also noted that, "[w]hether the s.15 analysis focuses on perpetuating disadvantage or stereotyping, the analysis involves looking at the circumstances of members of the group and the negative impact of the law on them. The analysis is contextual, not formalistic, grounded in the actual situation of the group and the potential of the impugned law to worsen their situation." (Withler at para 37). Moreover, the Court also noted however, that "[b]asing the s. 15(1) analysis on a comparison between the claimant group and a mirror comparator group has been criticized on the basis that a comparator group approach to s. 15(1) may substitute a formal "treat likes alike" analysis for the substantive equality analysis that has from the beginning been the focus of s. 15(1) jurisprudence." (Withler at para 55). The Supreme Court also stated that "a mirror comparator group analysis may fail to capture substantive inequality, may become a search for sameness, may shortcut the second stage of the substantive equality analysis, and may be difficult to apply. In all these ways, such an approach may fail to identify — and, indeed, thwart the identification of the discrimination at which s. 15 is aimed." (Withler at para 60). 
its home among those who seek to address systematic inequality and minimize economic, social and cultural oppression.

The result-oriented focus of substantive equality is vulnerable to critics as well. Those who see special treatment as philosophically inconsistent with the meaning of equality would necessarily resist efforts to change societal norms. ${ }^{32}$

Yet, for several reasons, the right to substantive equality has become particularly relevant for people with disabilities. ${ }^{33}$ First, because the substantive equality model focuses on results and outcomes, it stands as a reminder to all that disability and ability - as well as difference and sameness - are all relational. No one is "different" without a basis for comparison; and no one is disabled as long as there is one who, by comparison, is considered "abled." Without comparison, disability has no meaning. Thus, whom we label as different or not "normal" depends on whom we call normal. The new field of Disability Studies specifically seeks to recast the notion that normal is a fixed state by presenting normalcy as a social construction, defined by those in power to reinforce adherence to the current power hierarchy. ${ }^{34}$

A second reason why substantive equality has gained momentum in the disability rights community is that unlike laws which treat people differently because of their race, gender, religion or national origin, laws that offer different treatment based on disability may be considered justified and even necessary, in order to ensure equality. Interpreting equality in this way means that in addition to removing the legal barriers to equality of opportunities, society also must address the societal structures and attitudes that perpetuate discrimination and mistreatment of people with disabilities.

The substantive equality or equality of results or outcome model is therefore not about treating everyone the same, as is required under formal equality rather, it is about ensuring that the outcome or results for each person must be equal. As such, the purpose of providing accommodations becomes not merely about facilitating an entrance to a building or ensuring effective communication to a person who is Deaf, but is also about requiring structural changes in society. To achieve this result, the state has an obligation to ensure equality of outcomes, even if it means providing unequal treatment. Or, as Martha Minow has written, this "dilemma of difference" exists when we acknowledge that treating people differently is not always discrimination and that the same treatment does not always lead to more equality. ${ }^{35}$ To Minow, the "difference dilemma" means that for people with disabilities, segregation can be both protective of equality and violative of equality, depending upon the person. To achieve true equality, as Minow continues, we need "a shift in the paradigm we use to conceive of difference, a shift from a focus on the distinctions between people to a focus on the relationships within which we notice and draw distinctions." ${ }^{36}$ In short, society is required to rethink its structures,

32 Catherine MacKinnon, "Difference and Dominance: On Sex Discrimination” in D Kelly Weisberg, ed, Feminist Legal Theory: Foundations (Philadelphia: Temple University Press,1993) at 276-77.

33 See Kanter, supra note 25.

34 Ibid.

35 Martha Minow, Making All the Difference: Inclusion, Exclusion, and American Law (Ithaca, NY: Cornell University Print, 1991) 20.

36 Ibid. 
norms, and attitudes in order to achieve greater equality for all. The CRPD seeks to effectuate this shift for people with disabilities throughout the world.

\section{THE CRPD AND ITS PROMISE OF EQUALITY FOR PEOPLE WITH DISABILITIES}

The United Nations Convention on the Rights of Persons with Disabilities is the first treaty devoted exclusively to the rights of persons with disabilities. On its opening day, it was adopted by more countries than any other treaty in the history of the United Nations. ${ }^{37}$ As of today, it has already been ratified by 164 countries, representing 85 per cent of all member states of the UN. ${ }^{38}$

Despite its widespread adoption, the CRPD, alone, cannot ensure equality of results, equal opportunities or even formal equality for people with disabilities; no international treaty, without domestic implementation, can do that. On the other hand, the CRPD does represent the most comprehensive effort by the UN to ensure substantive equality for people with disabilities. It not only prohibits discrimination and mistreatment of people with disabilities worldwide, but it also guarantees many substantive rights to people with disabilities including the right to work, to an adequate standard of living, to health, among other rights, that had not previously been applied to people with disabilities under international law. ${ }^{39}$ Further, the CRPD guarantees these rights by challenging societal norms in a way that other international documents and many domestic laws do not. ${ }^{40}$ In the next section of this article, I discuss the particular challenges of ensuring equality for people with disabilities under international law and how the CRPD addresses these challenges and improves upon the existing concepts of equality for people with disabilities contained in U.S. and Canadian law.

\section{A. Equality Rights Under International Law Prior to the CRPD}

Prior to the CRPD, there were several international instruments that specifically addressed specific rights of people with disabilities; but none of these instruments was binding, and none sought to challenge the underlying prejudice and stigma that attaches to a label of disability in most countries in the world. ${ }^{41}$ Moreover, of the nine "core human rights treaties" that were binding, not one addresses specifically the rights of people with disabilities. ${ }^{42}$ Although one of

\footnotetext{
CRPD, supra note 19, art 1; See also Kanter, supra note 2 at 1.

United Nations Enable (12 Feb 2015), online: United Nations <http://www.un.org/disabilities/>.

CRPD, supra note 19.

Kanter, supra note 2 at 1.

Ibid.

42 Ibid at 21-35 (referring to UN General Assembly, Convention on the Elimination of All Forms of Discrimination against Women, 16 December 1966, 999 UNTS 171, online: Office of the High Commissioner for Human Rights $<$ http://www.ohchr.org/EN/ProfessionalInterest/Pages/CERD.aspx >.); UN General Assembly, International Covenant on Civil and Political Rights, 15 December 1989, 1642 UNTS 414, online: Office of the High Commissioner for Human Rights $<$ http://www.ohchr.org/en/professionalinterest/pages/ccpr.aspx>; UN General Assembly, International Covenant on Economic, Social and Cultural Rights, 16 December 1966, 993 UNTS 3, online: Office of the High Commissioner for Human Rights $<\mathrm{http}: / /$ www.ohchr.org/EN/ProfessionalInterest/Pages/CESCR.aspx>; UN General Assembly, Convention on the Elimination of All Forms of Discrimination against Women, 18 December 1979, 1249 UNTS 13, online:
} 
these core treaties, the Convention on the Rights of the Child [CRC], mentions children with disabilities, even the CRC does not recognize the right of children with disabilities to all of the same human rights protection as is provided to children without disabilities. ${ }^{43}$

Further, none of the disability-specific documents that were adopted prior to the CRPD includes a human rights approach to disability. ${ }^{44}$ A human rights approach to disability focuses on the protection of the rights of people with disabilities of all ages, gender, race, class and ethnicity, rather than (only) the social welfare needs of certain people with disabilities.

For example, the Declaration on the Rights of Mentally Retarded Persons (1971), ${ }^{45}$ and the Declaration on the Rights of Disabled Persons (1975), ${ }^{46}$ provide some protections to people with disabilities in certain contexts. However, neither of these documents are binding, and neither affirms unequivocally the right of people with disabilities to equality as a matter of international human rights law. It was not until 1982 when the UN adopted the World Programme of Action Concerning Disabled Persons, that the need to approach disability from a human rights perspective was recognized. The 1982 Programme affirms the right of people with disabilities to "equalization of opportunities" as a precondition for the achievement of full participation of persons with disabilities in all aspects of social and economic life. Following the World Programme, the Principles for the Protection of Persons with Mental Illness and for the Improvement of Mental Health Care (1991), ${ }^{47}$ and the Standard Rules on the Equalization of Opportunities for People with Disabilities (1993) ${ }^{48}$ also began to move closer to a human rights

Office of the High Commissioner for Human Rights <http://www.ohchr.org/EN/Professional-

Interest/Pages/CEDAW.aspx>; UN General Assembly, Convention against Torture and Other Cruel, Inhuman or Degrading Treatment or Punishment, 10 December 1984, 1465 UNTS 85, online: Office of the High Commissioner for Human Rights <http://www.ohchr.org/EN/ProfessionalInterest/Pages/CAT.aspx>; UN General Assembly, Convention on the Rights of the Child, 20 November 1989, 1577 UNTS 3, online; Office of the High Commissioner for Human Rights <http://www.ohchr.org/en/professionalinterest/pages/crc.aspx>; UN General Assembly, International Convention on the Protection of the Rights of All Migrant Workers and Members of Their Families, 18 December 1990, 2220 UNTS 3, online: Office of the High Commissioner for Human Rights $<\mathrm{http}: / /$ www.ohchr.org/EN/ProfessionalInterest/Pages/CMW.aspx $>$; UN General Assembly, International Convention for the Protection of All Persons from Enforced Disappearance, 20 December 2006, 2716 UNTS 3, online: Office of the High Commissioner for Human Rights $<$ http://www.ohchr.org/E-

N/ProfessionalInterest/Pages/IntConventionEnforcedDisappearance.aspx>; UN General Assembly, Convention on the Rights of Persons with Disabilities, 13 December 2006, 2515 UNTS 3, online: Office of the High Commissioner for Human Rights <http://www.ohchr.org/EN/HRBodies/CRPD/Pages/ConventionRightsPersonsWithDisabilities.aspx>.

43 UN General Assembly, Convention on the Rights of the Child, 20 November 1989, 1577 UNTS 3, art 2 para 1, online: Office of the High Commissioner for Human Rights $<$ http://www.ohchr.org/en/professionalinterest/pages/crc.aspx $>$.

44 Kanter, supra note 2 at 31, 35-36, 39-40.

45 Declaration on the Rights of Mentally Retarded Persons, GA Res 2856 (XXVI), 26 UNGAOR, Supp No 29, UN Doc A/8429 (1971) at 93.

46 Declaration on the Rights of Disabled Persons, GA Res 3447 (XXX), 30 UNGAOR, Supp No 34, UN Doc A/10034 (1975) at 88.

47 Principles for the Protection of Persons with Mental Illness and for the Improvement of Mental Health Care, UN Doc A/RES/46/119 (1991).

48 Standard Rules on the Equalization of Opportunities for Persons with Disabilities, UN Doc A/RES/48/96 (1993). 
approach to disability. But they too are non-binding and, like prior documents, they too fail to ensure equality of outcome or results for all people with disabilities. It was not until the adoption of the CRPD that people with disabilities were even recognized worldwide as a group worthy of equality under international human rights law.

\section{B. The Language of the CRPD}

To date, the CRPD has been ratified by 163 countries, including Canada, but not the U.S. ${ }^{49}$ The CRPD incorporates the social model of disability, which recognizes the obligation of societies to address the rights of people with disabilities by removing legal, attitudinal and physical barriers to their inclusion in society. ${ }^{50}$ This view stands in contrast to other models of disability, which focus primarily on people with disabilities as in need of charity, pity, or medical treatment. ${ }^{51}$ The CRPD affirms the social model by describing disability not as a condition that warrants medical treatment or society's pity, but rather as a condition arising from "interaction with various barriers [that] may hinder their full and effective participation in society on an equal basis with others" instead of inherent limitations. ${ }^{52}$ In this way, the CRPD rejects the long-standing medical model of disability, which has been described recently as "the most powerful influence on the conceptualisation of disability in modern history." ${ }^{, 53}$

The medical model, also known as the deficit model, views people with disabilities as "sick" and in need of medical intervention. ${ }^{54}$ This model locates the "problem" of disability within the person rather than in an environment that creates barriers to their full inclusion and participation. ${ }^{55}$ By contrast, the social model of disability places the problem of disability not on the individual, but squarely on the shoulders of the state that has the responsibility to remove structural, environmental, communication, legal, attitudinal, and all other barriers that "disable" certain people from interacting with society on an equal basis with others. ${ }^{56}$ Disability then is not so much about the presence of a physical, sensory, or mental impairment as it is about the social construction of difference.

\section{The CRPD and Equality in Employment}

The right to equality for people with disabilities is acknowledged throughout the CRPD. Article 3 specifically recognizes, as a general principle, the right of people with disabilities to "full and effective participation and inclusion in society,"

\footnotetext{
49 United Nations Enable, supra note 38. For a comprehensive discussion of the failure of the United States Senate to ratify the CRPD, see Arlene S Kanter, "The Americans with Disabilities Act at 25 Years: Lessons to Learn from the UN Convention on the Rights of People with Disabilities" (2015) 63 Drake L Rev 819 at 864-877.

50 Kanter, supra note 2 at 418.

51 Ibid.

52 CRPD, supra note 19, art 1.

53 Rosemary Kayess \& Phillip French, "Out of Darkness into Light? Introducing the Convention on the Rights of People with Disabilities, (2008) 8 Hum Rights L Rev 1 at 5.

54 Kanter, supra note 2 at 419-21.

55 Ibid.

56 Ibid at 426-28.

57 CRPD, supra note 19, art 3.
} 
Article 5 also requires States Parties to ensure the equality of persons with disabilities in their societies by, among other ways, prohibiting all types of discrimination "on the basis disability." ${ }^{29}$

The overall goal of the CRPD is to "promote, protect and ensure the full and equal enjoyment of all human rights and fundamental freedoms by all persons with disabilities, and to promote respect for their inherent dignity." ${ }^{60}$ The Preamble acknowledges that the treaty was motivated in large measure by the continuing exclusion of disabled persons, and the recognition of the many benefits that participation by disabled persons contribute to their respective societies. Paragraph (c) of the Preamble specifically affirms "the universality, indivisibility, interdependence and interrelatedness of all human rights and fundamental freedoms and the need for persons with disabilities to be guaranteed their full enjoyment without discrimination." ${ }^{, 61}$ Paragraph (m) goes further to acknowledge that "full participation by persons with disabilities will result in their enhanced sense of belonging and in significant advances in the human, social and economic development of society and the eradication of poverty." ${ }^{62}$ Such statements clearly go beyond a traditional "sameness" or "difference" model of equality.

I have argued elsewhere that the CRPD represents a new era in the development of disability rights law and an important step towards greater equality for people with disabilities - at least in those countries that choose to enforce its provisions. ${ }^{63}$ Here, I argue that the CRPD challenges policy makers, scholars, advocates, and activists to reframe the meaning of equality and inclusion for people with disabilities by requiring States Parties to take affirmative steps to ensure equality for people with disabilities that go beyond traditional notions of equal treatment as well as equal opportunities, specifically in the employment context.

\section{Article 27 of the CRPD}

Article 27 of the CRPD, entitled Work and Employment, is more than a prohibition of discrimination in the workplace. It recognizes also the right of all persons with disabilities to work on an equal basis with others, including their "right to the opportunity to gain a living by work freely chosen or accepted in a labour market and work environment that is open, inclusive and accessible to persons with disabilities." ${ }^{, 64}$ Article 27 also goes on to guarantee the right of persons with disabilities to "just and favourable conditions of work, including equal opportunities and equal remuneration for work of equal value, safe and healthy working conditions, including protection from harassment, and the redress of grievances." ${ }^{65}$ In addition to the right to accommodation for people with disabilities, Article 27 also includes the right to vocational training and placement services, assistance in obtaining, maintaining and returning to work, as well as opportunities for self-employment and affirmative action programs or incentives to

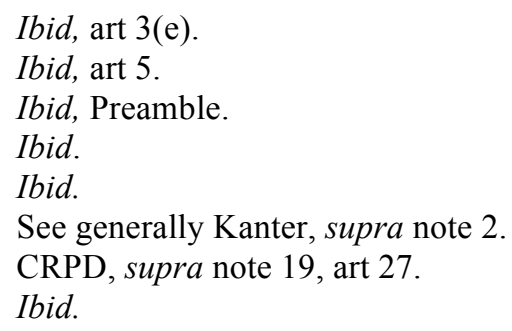


promote employment in the public and private sector. ${ }^{66}$ These provisions go far beyond a right to formal equality or even ensuring equal opportunities for people with disabilities. They seek to establish a new legal regime that counters oppressive workplace policies and practices. ${ }^{67}$

Moreover, unlike the $A D A$, which limits the definition of disability to those who have "a physical or mental impairment that substantially limits one or more of the major life activities, a record of such an impairment, or who is regarded as having such an impairment," ${ }^{68}$ the CRPD includes no definition per se of a person with a disability in Article 2, which explicitly contains other defined terms. ${ }^{69}$ To include an explicit definition of a person with a disability in the CRPD's definition section would have been considered by the $A d$ Hoc Committee as conceding a purely medical basis of disability. ${ }^{70}$ Instead, the CRPD adopts a social model of disability which requires an examination of the relationship between the individual and the many barriers in society that prevent his or her full inclusion. In this way, the CRPD drafters focused less on who is or is not covered by the treaty and more on the need to affirmatively change our respective societies' attitudes and practices toward people with disabilities. Indeed, no other international document includes such strong language regarding the responsibility of States Parties to remove barriers that prevent people with disabilities from realizing their right to equality under law. Although the CRPD does not specifically define who is or is not a person with a disability, it does include an open-ended commitment to cover those people "who have long-term physical, mental, intellectual or sensory impairments which in interaction with various barriers may hinder their full and effective participation in society on an equal basis with others." "71 This statement was the result of a compromise but nonetheless remains sufficiently broad to include at least those people who are also covered under some country's domestic disability laws, including the $A D A .^{72}$

66 Ibid.

67 Examples of countries that have adopted exemplary domestic employment laws and practices in response to the CRPD have been compiled by the Zero Project, a project that provides a platform to share innovative and effective solutions to problems that persons with disabilities face in countries throughout the world. For its 2013 compilation of innovative employment practices, see Zero Project, Innovative Policies 2015 on Independent Living \& Political Participation, online: Zero Project <http://zeroproject.org/policy-type/2013/>.

6842 USC $\S 12102(1)(2008) ; 29$ CFR $\S 1630.2(\mathrm{~g})(1)$.

69 CRPD, supra note 19, Preamble (e). The most extensive definition of disability in Canadian law is found in the Ontario (Human Rights Code, RSO 1990, c H-19 s 10).

70 Kanter, supra note 2 at 8.

71 CRPD, supra note 19, art 1.

72 See generally Kanter, supra note 25. The ADA Amendments Act of 2008 envisions the broadest possible coverage. For example, it includes within its coverage those people who have no impairment, but who are regarded by others as having an impairment (so long as the "regarded as" impairment is not transitory and minor). Supra note 68 at $\S 12102(3)(B)$. The $A D A A A$ also covers those people whose impairment is episodic or in remission, so long as it was substantially limiting when active. 42 USC $\S 12102(4)(D) ; 29$ CFR $§ 1630.15$ (f). The CRPD is also quite broad. Since it does not define the term" long term" nor specifically prohibit impairments of certain durations, it may also apply to people whose impairments are in remission or temporary. Further, although the CRPD also does not include the "regarded as" prong contained in the $A D A$ or the $A D A A A$, the CRPD Committee has not yet had an opportunity to interpret its coverage. Therefore, like the $A D A A A$, the CRPD also could apply to people who have no impairment but are regarded by others as having an impairment. In fact, given the CRPD's focus on the obligations of state parties to remove barriers, include attitudinal 
The CRPD also establishes for the first time under international law the right to accommodation as a free standing human right. The drafters of the CRPD recognized that lack of accommodation prevents many people with disabilities from being employed on an equal basis with those without disabilities. Article 5 of the General Principles of the CRPD therefore requires that "States Parties shall take all appropriate steps to ensure that reasonable accommodation is provided." ${ }^{, 73}$ Moreover, Article 2 of the CRPD includes denial of reasonable accommodation as a form of discrimination. ${ }^{74}$ In the CRPD, reasonable accommodation is both a form of nondiscriminatory treatment and a way to advance substantive equality by remedying harm that has been created by an inaccessible society. ${ }^{75}$ The CRPD, therefore, recognizes that changes in laws, policies and even long held societal practices must occur in order to help a person with a disability realize his or her potential. Rather than asking how the person with a disability will manage on his or her own, the CRPD requires us to ask: How can society be changed to ensure equal access and inclusion for people with disabilities? As a result, the CRPD introduces a broader concept of substantive equality for people with disabilities than that which was included in existing international human rights law or in other domestic disability laws.

In order to implement the rights included in Article 27, together with the general right to equality and reasonable accommodations in Articles 3 and 5, also means eliminating the distinction between positive and negative rights. The CRPD transforms rights that in the past had been considered negative rights, into positive State obligations. Thus, the right to equality in the CRPD not only seeks to ensure freedom from restrictions but also guarantees the affirmative right to equal physical and communication access and accommodations, as needed. For example, Article 4 of the General Principles requires States Parties to "take all appropriate measures, including legislation, to modify or abolish existing laws, regulations, customs and practices that constitute discrimination against persons with disabilities." 76 This provision also requires States Parties to take affirmative steps to actually change society by challenging stereotypes and promoting the inherent dignity, worth, and "equal and inalienable rights" proclaimed in the Preamble. ${ }^{77}$

The requirement of societal changes with respect to people with disabilities is also included in Article 8. Article 8 requires States Parties to "adopt immediate, effective and appropriate measures: (a) to raise awareness...and to foster respect for the rights and dignity of persons with disabilities; (b) to combat stereotypes, prejudices, and harmful practices relating to persons with disabilities, including those based on sex and age, in all areas of life; and (c) to promote awareness of the capabilities and contributions of persons with disabilities." ${ }^{, 78}$ It also requires States Parties "to foster an attitude of respect for the rights of persons with disabilities...to

\footnotetext{
barriers, the CRPD may be interpreted to apply to people who are regarded as disabled, even in the absence of such an express provision.

CRPD, supra note 19, art 5.

Ibid, art 2.

5 Kayess \& French, supra note 56. Although reasonable accommodation is provided on an individual basis, it also has the potential to fundamentally transform the norms within a society.

6 CRPD, supra note 19, art 4.

7 Ibid, Preamble.
}

$78 \quad$ Ibid, art 8. 
encourage all organs of the media to portray persons with disabilities in a manner consistent with the purpose of the present Convention." 79 Article 8 therefore shifts the responsibility for the exclusion of people with disabilities from the person's particular situation, diagnosis or disability to the government and the greater society. This is exactly the shift that the right to substantive equality dictates. No prior treaty includes a separate article on awareness raising, and no stronger language could have been included to show the urgency and priority of raising awareness about disability rights as an integral goal of the CRPD in combating the exclusion of people with disabilities from society.

But, even more important than awareness-raising in Article 8 is the need to promote the realization of the purpose and objectives of the CRPD through the adoption of national laws and policies. Article 32 addresses this need by referring to specific implementation measures that can be used to change society by specifying "appropriate and effective measures." ${ }^{\text {" }}$ "Such measures include: (a) ensuring that international development programmes are inclusive of and accessible to persons with disabilities; (b) facilitating and supporting capacity-building, including through the exchange and sharing of information, experiences, training programmes and best practices; (c) facilitating cooperation in research and access to scientific and technical knowledge; and (d) providing, technical and economic assistance, including by facilitating access to and sharing of accessible and assistive technologies, and through the transfer of technologies. ${ }^{81}$ Article 32 , therefore, requires States Parties to include people with disabilities at every step of the process based on the realization that without people with disabilities included as the experts, stakeholders and decision makers, little real change can take place. Indeed, the CRPD itself is an example of the accomplishments of people with disabilities, as evidenced by their role in the drafting process.

The CRPD also requires the creation of a focal point and an independent mechanism within the government for the "promotion, protection, and monitoring" of the Convention. ${ }^{82}$ Article 31 also requires the collection and dissemination of statistical information to "facilitate the development and application of implementation policies." 83 Finally, the Optional Protocol to the CRPD mandates even greater monitoring and implementation measures than in previous treaties, at least in those countries that ratify it. ${ }^{84}$ In short, the CRPD in Article 27 as well as other articles, illustrates the way in which the CRPD challenges traditional anti-discrimination law and seeks to ensure greater equality for people with disabilities.

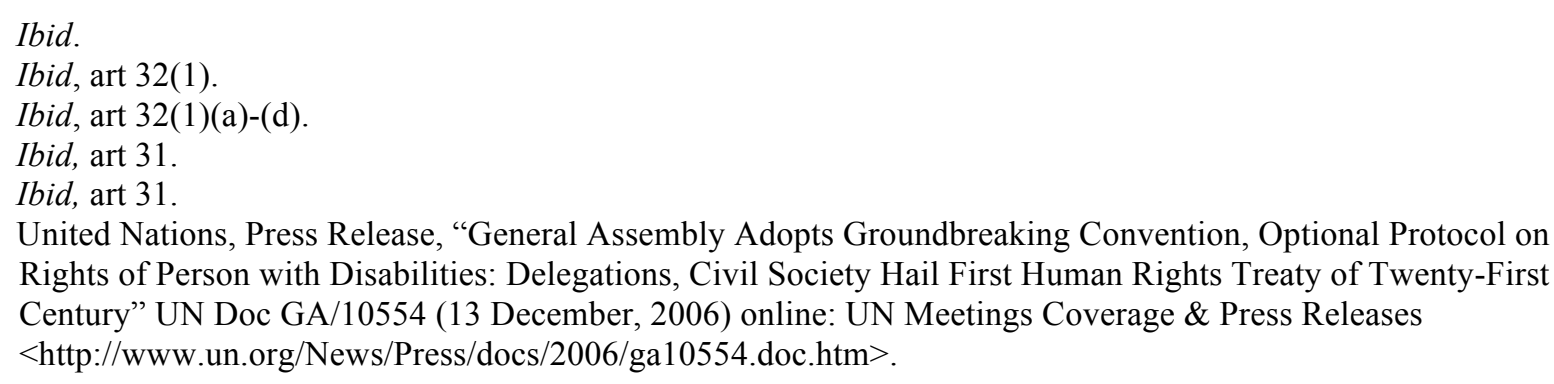




\section{The Elusive Right to Equality for People with Disabilities Under U.S. Law}

The CRPD has the potential not only to improve access for Americans with disabilities who live, work, and travel abroad, ${ }^{85}$ but also to influence U.S. law, particularly with respect to equality for people with disabilities in the workplace.

In the United States, the right to equality for people with disabilities is not guaranteed under the Constitution. Neither the Due Process Clause nor the Equal Protection Clause of the Fourteenth Amendment of the Constitution mention disability. Further, in the United States, there is no "right" to work. Although the Supreme Court has held that "the right to hold specific private employment and to follow a chosen profession free from unreasonable governmental interference comes within the 'liberty' and 'property' concepts of the Fifth Amendment, there is no constitutional right to work per se." ${ }^{\prime 6}$ The U.S. Constitution may protect certain employmentrelated rights but only negative rights; it does not give any individual a positive right to work or to work at a particular job. Under the Due Process Clause, states are still free to regulate employment, and courts will generally defer to such state actions. ${ }^{87}$ Moreover, challenges to state action are subject to the lowest level of judicial scrutiny, known as "the rational basis test." 88 Thus although the Fourteenth Amendment to the U.S. Constitution prohibits the State from denying "any person within its jurisdiction the equal protection of the laws," 89 decisions by the U.S. Supreme Court have limited such protections to certain identifiable groups, but not to people with disabilities.

For example, in Cleburne $v$ Cleburne Living Center, ${ }^{90}$ the U.S. Supreme Court was asked to determine whether people with mental disabilities, as a group, were entitled to a heightened level of review under the Fourteenth Amendment's Equal Protection Clause. Together with the briefs filed by amici curiae, the parties gave the Court a choice to find that people with disabilities should be entitled to a mid-level review under the Equal Protection Clause or to find that people with disabilities should be entitled to the highest level of review, or strict scrutiny, since, like people who experience discrimination on the basis of race, people with disabilities also have experienced centuries-long exclusion, denial of voting and other rights, and widespread discrimination. Applying only the lowest standard of review, known as the rational basis test, the Court held that the 13 people with "mental retardation" (the now outdated term used in the case) were not entitled to any special protections under the Equal Protection Clause and that the city was permitted to enact zoning laws. ${ }^{91}$ However, because the city could not provide even a rational basis for its exclusionary zoning policy, the Court ruled against the city, and the group home was allowed to open. ${ }^{92}$ Most of the justices agreed with the final decision, but a vocal minority would have held that people with disabilities are entitled to special protection of the laws in the same

85 National Council on Disability, NCD Statement on the Convention on the Rights of Persons with Disabilities (14 July 2014), online: National Council on Disability <http://www.ncd.gov/publications/2014/07142014/ . United States $v$ Robel, 389 US 258, $265 \mathrm{n} 11$ (1967).

See United States $v$ Carolene Products Co, 304 US 144, 151 (1938).

Ibid. See also Cleburne v Cleburne Living Center, 473 US 432 (1985).

US Const amend XIV $\S 1$.

Cleburne, supra note 88 .

Ibid.

Ibid. 
way as are other groups who receive special protections under the Equal Protection Clause. ${ }^{93}$ In the end, the Supreme Court refused to provide heightened scrutiny to the city's actions in this case. But even using the least stringent test, the Court held that that the city's permit scheme violated the rights of the residents. According to this Court, therefore, being disabled may sometimes justify legislative distinctions, but not always. The Supreme Court made it clear that so long as a state acts "rationally," it will not second-guess the state's decisions, at least with respect to people with disabilities. Thus, although the Court found that the city in this case had acted irrationally and that there was no legitimate basis for their denial of the permit, ${ }^{94}$ in most other cases, the Court conceded that the state would prevail because rationality requires only minimal justification. ${ }^{95}$ As the Court observed, "if the potential residents of the ... home were not mentally retarded, but the home was the same in all other respects, its use would be permitted under the city's zoning ordinance. ${ }^{96}$

Having recognized the limits of constitutional protections for people with disabilities, advocates for the protection of the rights of people with disabilities worked long and hard, first, to amend the Civil Rights Act of 1964, to add disability to the other groups protected in that law, and then, when that failed, to enact a new law specifically designed to eradicate discrimination on the basis of disability. Discrimination against people with disabilities by the federal government and programs and contractors of the federal government had already been prohibited since 1973 when the Rehabilitation Act was enacted. ${ }^{97}$ As a civil rights law, however, the $A D A$ is more limited than both the CRPD and the Canadian Charter of Rights and Freedoms [Charter]. ${ }^{98}$

\section{The Prohibition of Employment Discrimination in the Americans with Disabilities Act}

The Americans with Disabilities Act, known as the $A D A,{ }^{99}$ was enacted to "provide a clear and comprehensive national mandate for the elimination of discrimination against individuals with disabilities ... [and] to assure equality of opportunity, full participation, independent living, and economic self-sufficiency for such individuals." 100 The original version of the $A D A$ was signed into law on July 26, 1990, after overwhelming bipartisan support by Congress. ${ }^{101}$ The day of the

93 The Court held that people with disabilities do not qualify as a "suspect class" under the Equal Protection Clause. Cleburne, ibid at 432; But see opinion by Justice Marshall, concurring in part and dissenting in part, joined by Justices Brennan and Blackman, on the issue of the appropriate level of review under the 14th Amendment 473 US at $455-478$.

94 Cleburne, ibid.

95 Ibid at 439 (citing Plyler v Doe, 457 US 202, 216 (1982)).

96 Cleburne, ibid at 437.

97 Rehabilitation Act of 1973, 29 USC $\S \S 791-94$ (1973).

98 "The Canadian Charter is, in essence, a bill of rights. The Federal Government of Canada "enacted first the Canadian Bill of Rights, SC 1960, c 44, reprinted in RSC 1985, App III and then the Canadian Charter of Rights and Freedoms in 1982, the latter having constitutional status. The values reflected in the Charter were to be the foundation of all laws, part of the "'supreme law of Canada' against which the constitutionality of all other laws was to be measured." McKinney v University of Guelph, [1990] 3 SCR at 355, Wilson J, dissenting. as set forth in 1994 OLC Lexis 36, footnote 17.

99 ADA, supra note $19, \S \S 12101-12300$.

100 Ibid, $\S \S 12101$ et seq.

10142 USCA $\S \S 12103-12213$ (West Supp. 1991). 
$A D A$ 's enactment has been termed "Liberation Day of the Disabled"102 and the $A D A$, itself, as the "Emancipation Proclamation" for people with disabilities. ${ }^{103}$ The $A D A$ sought to extend equality of treatment to millions of Americans with disabilities, just as civil rights legislation of the previous generation had sought to advance equal treatment for all, regardless of race, religion, national origin, gender, color, and age. ${ }^{104}$ The $A D A$ was and is considered the "most comprehensive civil rights legislation passed by Congress since the 1964 Civil Rights Act.

In the $A D A$ 's "Findings and Purpose" statement, Congress found that 43 million Americans have one or more physical or mental disabilities, and that the number is increasing. Historically, people with disabilities in the United States have been isolated, segregated and otherwise discriminated against in all areas of life including employment, housing, education, communication, recreation, and access to public accommodations and services. ${ }^{105}$ Congress found further that such discrimination has been intentional due to assumptions "based on characteristics that are beyond the control of such individuals and resulting from stereotypical assumptions not truly indicative of the individual ability of such individuals to participate in, and contribute to society." $" 106$

In regard to employment rights, in particular, Title I of the $A D A$ seeks to bring people with disabilities into the employment sector by prohibiting discrimination on the basis of disability. ${ }^{107}$ Yet Title I is limited only to prohibiting discrimination; whereas Article 27 of the CRPD addresses discrimination as well as the chronic un- and underemployment of people with disabilities. Article 27 does this by imposing on state actors affirmative duties to promote employment of people with disabilities through incentives, set-asides, quotas, as well as vocational training and other job promoting programs. ${ }^{108}$ Moreover, the CRPD goes beyond prohibiting employment discrimination to guaranteeing, for the first time in international law, the right of all people with disabilities to work in Article 27, and the right to an adequate standard of living and social protection in Article 28. Neither the $A D A$ nor any other U.S. law addresses economic or social protections as rights.

Further, even as a discrimination law, Title I of the $A D A$ is limited by its definitions and exclusions. Not all employees with disabilities are protected under the law and not all employers or employment settings are covered by the law. Title I of the $A D A$ provides that "no covered entity shall discriminate against a qualified individual with a disability because of the disability of

102 Stephen Chapman, "Waving a Magic Wand at the Needs of the Handicapped" Chicago Tribune (24 September 1989), online: Chicago Tribune < http://articles.chicagotribune.com/19890924/news/8901150683_1_handicapped-wand-disabled>; $A D A$, supra note $18, \S 4-3$ (the $A D A$ has been dubbed "Liberation Day of the disabled.").

103 US, 136 Cong Rec S9689 (Daily Digest 13 July 1990) (statement of Senator Harkin).

104 Civil Rights Act of 1964, 42 USC § 2000e-2 (1981); The Age Discrimination in Employment Act of 1967, 29 USC $\S 623$ (1985).

105 See Kanter, generally supra note 25. Steven F Stuhlbarg, "Reasonable Accommodation under the Americans with Disabilities Act: How Much Must One Do Before Hardship Turns Undue?” (1991) 59 U Cin Rev 1311 at 1311, quoted in "The Americans With Disabilities Act: Great Progress, Greater Potential" (1996) 109 Harv L Rev 1602 at 1603 .

106 ADA, supra note $19, \S 12101(\mathrm{a})(7)$.

107 Ibid, § 12112(a).

108 CRPD, supra note 19, art 27. 
such individual in regard to job application procedures, the hiring, advancement, or discharge of employees, employee compensation, job training, and other terms, conditions, and privileges of employment." ${ }^{109}$ Since July 26, 1994, Title I has applied to private employers who are "engaged in an industry affecting commerce who has 15 or more employees for each working day in each of 20 or more calendar weeks in the current or preceding calendar year, and any agent of such person...", ${ }^{110}$ Title I also limits the context in which claims of employment discrimination may arise to "job application procedures, hiring, job training, and other terms, conditions, and privileges of employment." 111

The statute also lists several actions by employers that would constitute discrimination. These actions include classifying or limiting a job applicant or employee based on his or her disability, failing to make reasonable accommodations to a person with a disability, and using selection criteria that screen out individuals with disabilities, including the use of tests or examinations. ${ }^{112}$ The $A D A$ also specifically prohibits pre-employment inquiries regarding whether the applicant has a disability and the nature or severity of the disability. ${ }^{113}$ However, the employer is free to identify the essential functions of the job at issue and to ask whether the applicant can perform these essential functions. ${ }^{114}$ Congress also provided a defense to employers to such requirements if the action would "require significant difficulty or expense." employers who can show that attempts to screen out applicants or employees with disabilities are required as "job related and consistent with business necessity." "116 The final defense available to employers is known as the "direct threat defense." Here, the employer may refute an allegation of disability discrimination by showing that the individual poses a "direct threat to the health or safety of other individuals in the workplace." ${ }^{\prime 17}$ A direct threat is defined in the $A D A$ regulations as a "significant risk of substantial harm" to the disabled individual or to others that cannot be reduced or eliminated by reasonable accommodation. ${ }^{118}$

Discrimination is defined as, among other things, "not making reasonable accommodations to the known physical or mental limitations of an otherwise qualified individual with a disability who is an applicant or employee, unless such covered entity can demonstrate that the accommodation would impose an undue hardship on the operation of the business of such covered entity; or...denying employment opportunities to a job applicant or employee who is an otherwise qualified individual with a disability, if such denial is based on the need of such covered entity to make reasonable accommodation to the physical or mental impairments of the

$09 A D A$, supra note $19, \S 12112(\mathrm{a})$.

110 Ibid, § 12111.

111 Ibid, $\S 12112(\mathrm{a})$.

112 Ibid, $\$ \S 12112(\mathrm{~b})(1),(5),(6)$ (Supp V).

113 Ibid, $\S \S 12112(\mathrm{~b})(6),(\mathrm{d})(2)(\mathrm{A})$ (Supp V).

14 Ibid, $\S \S 12112(\mathrm{~d})(2)(\mathrm{B})($ Supp V).

Ibid, $\S 12111(10)(\mathrm{A})$

116 Ibid, §12113(a) (Supp V); See Regulations to Implement the Equal Employment Provisions of the Americans with Disabilities Act, 29 CFR $\S 1630.15(a)$ (1995).

117 Ibid, §12113(b) (Supp V).

118 Regulations, supra note 116 at $\$ 1630.2(\mathrm{r})(1995)$. 
employee or applicant."119 Title I defines reasonable accommodation to include "making existing facilities used by employees readily accessible to and usable by individuals with disabilities;... and job restructuring, part-time or modified work schedules, reassignment to a vacant position, acquisition or modification of equipment or devices, appropriate adjustment or modifications of examinations, training materials or policies, the provision of qualified readers or interpreters, and other similar accommodations for individuals with disabilities." does not have to provide an accommodation that would be an undue hardship defined as an action that would require significant difficulty or expense"121 or one that would pose a direct threat to the health or safety of others in the workplace. ${ }^{122}$

But even the limited concept of reasonable accommodation in the $A D A$ differs from its broader reach in the CRPD. Under the CRPD, employers would be required to "take all appropriate steps to ensure that reasonable accommodation is provided" or provide "[s]pecific measures" that "accelerate or achieve de facto equality of persons with disabilities."123 Thus, employment programs that are mentioned in the CRPD such as affirmative action, quotas and set asides "are beyond the concept of equality as currently understood in U.S. law and politics." 124

Perhaps even more controversial than what constitutes discrimination under Title I of the $A D A$ is the issue of who is entitled to protection as a "qualified individual with a disability" under Title I. Congress recognized in its original findings in the $A D A$ that persons with disabilities constitute a discrete and insular minority and that "unlike individuals who have experienced discrimination on the basis of race, color, sex national origin, religion or age, individuals who have experienced discrimination on the basis of disability have often had no legal recourse to redress such discrimination. ${ }^{125}$ But Congress also exercised its discretion in deciding who would be included and excluded from protection under the original version of the $A D A$ in 1990 as well as in the Americans with Disabilities Amendments Act in 2008. ${ }^{126}$

119 ADA, supra note $19, \S 12112(\mathrm{~b})(5)(\mathrm{A}-\mathrm{B})$.

120 Ibid, § 12111(9).

121 Ibid, $\S 12112(10)(\mathrm{A})$. The factors to be considered in finding undue hardship include (i) the nature and cost of the accommodation needed under this chapter; (ii) the overall financial resources of the facility or facilities involved in the provision of the reasonable accommodation; the number of persons employed at such facility; the effect on expenses and resources, or the impact otherwise of such accommodation upon the operation of the facility; (iii) the overall financial resources of the covered entity; the overall size of the business of a covered entity with respect to the number of its employees; the number, type, and location of its facilities; and (iv) the type of operation or operations of the covered entity, including the composition, structure, and functions of the workforce of such entity; the geographic separateness, administrative, or fiscal relationship of the facility or facilities in question to the covered entity." Ibid, $\$ 12112(10)(\mathrm{C})(\mathrm{i}-\mathrm{iv})$.

122 See ibid, §12111(3). See also Chevron USA Inc v Echazabal, 536 US 75 (2002) (extending "direct threat" defense to harm to self).

123 CRPD, supra note 19, art 5.

124 National Council on Disability, "Finding the Gaps: A Comparative Analysis of Disability Laws in the United States to the United Nations Convention on the Rights of Persons with Disabilities", online: (2008) $<$ https://www.ncd.gov/rawmedia_repository/bbae6ede_8719_48b8_b40f_33938b9a2189.pdf $>$. The NCD goes on to state, "These types of schemes, however, are within Congress's spending power to authorize if it so chooses." Ibid.

125 ADA, supra note 19, § 12101(a)(4).

126 Ibid, § 12211; Regulations, supra note 117 at $\S 630.3(\mathrm{~d})$. 
For example, Title I protects people who have a history of drug abuse but who have successfully completed or who are currently enrolled in a supervised drug rehabilitation program and are no longer engaging in the illegal use of drugs as well as people who are alcoholics. ${ }^{127}$ As such, the $A D A$ 's definition of disability is one of the most comprehensive in the world. ${ }^{128}$ On the other hand, the $A D A$ includes specific exclusions for "transvestitism, transsexualism, pedophilia, exhibitionism, voyeurism, gender identity disorders not resulting from physical impairments or other sexual behaviour disorders," as well as "compulsive gambling, kleptomania, pyromania, or psychoactive substance use disorders resulting from current illegal use of drugs.",129 Although gender identity related issues are not disabilities (certainly not according to those of different gender identities), the other conditions exempted from $A D A$ coverage were still considered impairments similar to those included within the definition of disability. Thus Congress' decision to exclude certain categories of impairment was more likely the result of a political compromise recognizing the changing view of certain identities and traits, than a decision based on the prevalence of discrimination experienced by certain groups.

In addition to the exclusions, the definition of disability itself has undergone revisions since it was first introduced in the original version of the $A D A$ in 1990. After Congress found that the Supreme Court had improperly limited the definition of disability in three 1999 Title I $A D A$ cases ${ }^{130}$ Congress amended the $A D A$ in 2008 with the new Americans with Disabilities Amendments Act [ADAAA]. The stated purpose of the ADAAA is to "reject the Supreme Court's reasoning" in the 1999 cases and to "reinstat[e] a broad scope of protection to be available under the $A D A . " 131$ Congress found that persons with many types of impairments - including epilepsy, diabetes, multiple sclerosis, intellectual disabilities (formerly called mental retardation), major depression and bipolar disorder - had been unable to bring $A D A$ claims because they were found not to meet the $A D A$ 's definition of "disability." By enacting the $A D A A A$, Congress chose to create presumptions in favor of protection for most groups of people with disabilities who were not specifically excluded.

The $A D A A A$ retains, however, the original three prongs of the $A D A$, which define disability to mean, with respect to an individual, one who has (1) a physical or mental impairment that substantially limits one or more major life activities; (2) a record of such impairment; or (3) being regarded as having such an impairment. ${ }^{132}$ Even though the $A D A A A$ now makes clear that

\footnotetext{
Ibid, § 12114 (b)-(c).

Kanter, supra note 2.

129 ADA, supra note 19 at $\S 12211$; Regulations, supra note 116 at $\S 630.3(\mathrm{~d})$. Although the Supreme Court of Canada, has not yet ruled on trans identity or gender identity under the Canadian Charter or any statutory human rights legislation, trans identity has begun to be recognized in a number of human rights acts in Canada as a prohibited ground of discrimination, such as in Ontario (Human Rights Code, RSO 1990, c H-19), the Northwest Territories (Human Rights Act, SNWT 2004, c 18), Manitoba (Human Rights Code, CCSM 1987, c H-175), and Nova Scotia (Human Rights Act, RS 1989, c 214).

130 Sutton v United Airlines, 527 US 471 (1999); Murphy v United Parcel Service, 527 US 516 (1999); Albertson's Inc v Kirkingburg, 527 US 555 (1999); Toyota Motor Manufacturing v Williams, 534 US 184 (2002).

13142 USCA § $12010(\mathrm{~b})(1),(3)$.

132 Ibid, § 12102(1) (2008).
} 
the definition of disability is to be construed broadly, it nonetheless fails to ensure substantive equality to all people with disabilities.

The $A D A A A$ like the $A D A$ before it, protects only "qualified" employees. ${ }^{133}$ Thus, an employer would not violate the $A D A$ by refusing to hire a person with a disability if the person is not qualified to do the job. The issue of 'qualification' is, however, subjective. As a result, this issue will continue to be the subject of litigation, even after the clarifying amendments of $2008 .{ }^{134}$

Although Title I is limited in its scope and coverage, it is consistent with the limited overall goal of the $A D A A A$. The $A D A A A$, like the $A D A$ before it, is an anti-discrimination law; it was never intended to ensure substantive equality for people with disabilities. In fact, one may argue that the primary motive behind the $A D A$ was not to ensure equality at all, but to move people with disabilities from dependency on the government for assistance to self-sufficiency. ${ }^{135}$ This view of the $A D A$ as a law that would essentially save the government money is seen in the original preamble to the $A D A$ in which Congress found that discrimination against people with disabilities costs the United States several billion dollars in "unnecessary expenses resulting from dependency and non-productivity." "136 As one legal scholar recently observed, the intent of the $A D A$ was not to ensure equality but rather to eliminate certain obstacles that prevent people with disabilities from working and becoming productive members of society. ${ }^{137}$ One of the architects of the original version of the $A D A$ acknowledges that equality for people with disabilities was not even on their minds as they drafted the $A D A$. As she wrote,

As drafters of the $A D A$, we never discussed theories of equality. Using the rhetoric of traditional civil rights, which focuses on equal treatment, we incorporated nondiscrimination provisions from section 504 implementing regulations that assured that different treatment would be provided when necessary to achieve equal opportunity. We were insistent that reasonable accommodation was not affirmative action but simply part and parcel of meaningful nondiscrimination. Unlike the women's movement, which has been hotly debating the wisdom of ever veering from the equal treatment paradigm, the disability movement has known from the outset that for people with disabilities, a civil rights statute based solely on equal treatment would fall far short of achieving the goals of inclusion and participation. ${ }^{138}$

133 Ibid, § 12111(8).

134 See e.g. Morriss v BNFY Ry. Co, 2016 U.S. App. LEXIS 6179 ( $8^{\text {th }}$ Cir. 2016); Jacobs v. N.C. Admin. Office of Courts, 780 F.3d 562 ( $4^{\text {th }}$ Cir. 2015); Burton v. Freescale Semiconductor Inc 798 F.3d 222 (5 ${ }^{\text {th }}$ Cir. 2015); Minnihan v. Mediacom Communications Corp., 779 F.3d 803 ( $8^{\text {th }}$ Cir. 2015); Summers v. Altarum Institute, 740 F.3d 325 ( $4^{\text {th }}$ Cir. 2014); Felkins v City of Lakewood, 774 F.3d 647 (10 ${ }^{\text {th }}$ Cir. 2014).

135 See Kanter generally supra note 25; Samuel R Bagenstos, Law and the Contradictions of the Disability Rights Movement (New Haven: Yale University Press, 2009).

13642 USC §12101(a)(9) (1990).

137 Bagenstos, supra note 135 at 113.

138 Mayerson \& Yee, supra note 4. 
Thus, while the United States is hailed as a forerunner to progressive disability rights legislation worldwide, the scope and coverage of its $A D A$, together with its Supreme Court's narrow interpretation of the meaning of equality as applied to people with disabilities, continues to limit the promise of substantive equality for people with disabilities under U.S. law.

\section{THE RIGHT TO SUBSTANTIVE EQUALITY UNDER CANADIAN LAW}

\section{A. The Canadian Charter of Rights and Freedoms}

Canadian legislators and courts have been more open to claims for substantive equality for people with disabilities than have their counterparts in the U.S. Although the original proposed wording of the equality provision of Canadian Charter of Rights and Freedoms did not include disability as a protected category, this proposed wording was modified in 1981 to include physical and mental disability. ${ }^{139}$ Section 15 the Charter now provides that "[e]very individual is equal before and under the law and has the right to the equal protection and equal benefit of the law without discrimination and, in particular, without discrimination based on race, national or ethnic origin, colour, religion, sex, age or mental or physical disability." "140 Unlike civil rights laws, generally, the Charter does not merely provide individual remedies; it also requires the immediate invalidation of any law or government policy or program that is found to violate the Charter. ${ }^{141}$

The Charter is "structured upon a very broad equality clause contained in Canada's constitution, as well as human rights laws that define disability quite broadly." 142 Evidence of the broad meaning of equality for people with disabilities is seen in the oft-cited 1989 case of Andrews v Law Society of British Columbia. ${ }^{143}$ While sitting on the British Columbia Court of Appeal, Justice McLachlin interpreted Section 15 of the Canadian Charter of Rights and Freedoms to provide more than formal equality or even equality of opportunities. ${ }^{144}$ As Justice McLachlin explained extrajudicially:

139 For a comprehensive discussion of the process that lead to including mental and physical disability as protected grounds in the Charter, see Yvonne Peters, "Twenty Years of Litigating for Disability Equality Rights: Has it Made a Difference? An Assessment by the Council of Canadians with Disabilities", online: (2004) $<$ http://www.ccdonline.ca/en/humanrights/promoting/20years\&sa=U\&ei=WE1YU_XyClyA2QX8tYGgDg\&ve $\mathrm{d}=0 \mathrm{CBsQFjAA \& usg=AFQjCNGos2M6Uv2C0ywpxzpvOOnS4IMMXw \geq .}$

140 See Colm O'Cinneide, "Extracting Protection for the Rights of Persons with Disabilities" in Oddny M Arnardottir \& Gerard Quinn, eds, The UN Convention on the Rights of Persons with Disabilities: European and Scandinavian Perspectives (Leiden: Martinus Nijhoff Publishers, 2009) 176; See also Sarah Armstrong, "Disability Advocacy in the Charter Era", (2003) 2:1 JL \& Equality 33.

141 See the Civil Rights Act of 1964, 42 USC § 2000e-5 et seq (1981) and the Canadian Charter, supra note 3, s 39.

142 Peters, supra note 140.

143 Andrews v Law Society of British Columbia, [1989] 1 SCR 143.

144 Gwen Brodsky \& Shelagh Day, "Beyond the Social and Economic Rights Debate: Substantive Equality Speaks to Poverty", (2008) 14 CJWL 184 at 208 (quoting McLachlin CJ, "The Evolution of Equality" (1996) 54 The Advocate 559 at 564). In Andrews, the Supreme Court of Canada found the purpose of section 15 of the Charter was "not only to prevent the attribution of stereotypical characteristics to individuals, but also to ameliorate the position of groups within Canadian society who have suffered disadvantage by exclusion from mainstream society." Andrews, ibid at para 65. 
The Andrews decision...pointed out the potential vacuity of formalistic concepts of equality and emphasized the need to look at the reality of how differential treatment impacts on the lives of members of stigmatized groups. The purpose of the Charter guarantee of equality, the Court affirmed, was not to guarantee some abstract notion of similar treatment for the similarly situated...[but] rather to better the situation of members of groups which had traditionally been subordinated and disadvantaged. $^{145}$

This quoted language provided the foundation upon which later decisions by Canadian courts were able to deliver on a promise of greater substantive equality for people with disabilities, as is exemplified in the discussion of the following cases.

In the landmark and unanimous decision in Eldridge $v$ British Columbia, the Supreme Court of Canada held that the denial of sign language interpreters to deaf individuals in medical settings constituted discrimination under s. 15 of the Charter. ${ }^{146}$ The Supreme Court reasoned that the effect of a policy denying sign language interpreters to deaf individuals was to prevent them from communicating with medical staff. ${ }^{147}$ The court held therefore that sign language interpretation was "necessary for effective communication in the delivery of medical services". 148 Moreover, at the minimum impairment stage of the proportionality test, the Court noted that the projected cost of providing interpreter services was $\$ 150,000$, compared to a total provincial health care budget of over $\$ 6$ billion. ${ }^{149}$ The unanimous Court concluded that the facially neutral law at issue offended s. 15 of the Charter because of its adverse effects on people who are deaf and that it could not be saved by s.1.

The Eldridge decision was welcomed by the disability community as a positive step towards "giving real effect to equality" in Canada. ${ }^{150}$ In its decision, the Court specifically distinguished its view of discrimination from that of the United States' Supreme Court, which requires a discriminatory intent in order to find an equal protection violation under the Fourteenth Amendment of the U.S. Constitution. ${ }^{151}$ The Court in Eldridge acknowledged that "to promote the objective of the more equal society, s. 15(1) [of the Canadian Charter] acts as a bar to the executive enacting provisions without taking into account their possible impact on already disadvantaged classes of persons." 152 Moreover, the Court concluded that in order to ensure equality, a government "may be required to take positive steps to ensure the equality of people or groups who come within the scope of s. 15 [of the Canadian Charter]." ${ }^{\text {"153 }}$ The Court also

\footnotetext{
145 Brodsky \& Day, ibid.

146 Eldridge v British Colombia (Attorney General), [1998] 3 SCR 624.

147 Ibid.

148 Ibid at para 96.

49 Ibid at para 87.

150 Martha Jackman, “'Giving Real Effect to Equality:' Eldridge v British Columbia (Attorney General) and Vriend v Alberta", (1998) 4:2 Rev Const Stud 352 at 353.

151 Eldridge, supra note 146 at para 62.

152 Ibid at para 64 (quoting Rodriguez v British Columbia (Attorney General), [1993] 3 SCR 519 at 549.

153 Ibid at para 79.
} 
recognized that "a commitment ... to the equal worth and human dignity of all persons" be protected by the state and that [d]ignity requires respect, and respect is acknowledgment of human dignity." $" 155$ This Court's recognition of the importance of ensuring protection for substantive equality as well as dignity for people with disabilities stands in sharp contrast to some U.S. court decisions which refused to even consider the humiliating effect of allegedly discriminatory conduct on the individual with a disability as a violation of the right to equality. ${ }^{156}$

The Eldridge decision echoes the sentiments of the Canadian Supreme Court in an earlier case, decided in 1996. In Eaton v Brant (County) Board of Education, the Court stated that "accommodation of differences ... is the true essence of equality." the purpose of section 15(1) of the Charter "is not only to prevent discrimination by the attribution of stereotypical characteristics to individuals, but also to ameliorate the position of groups within Canadian society who have suffered disadvantage by exclusion from mainstream society as has been the case with disabled persons." ${ }^{158}$

Despite the Court's affirmation of the right to equality and dignity for people with disabilities in the Eaton and Eldridge decisions, the Court is not always as generous in its interpretation of s. 15 of the Charter. For example, the case of Law v Canada (Minister of Employment and Immigration), the Court refused to provide protection from discrimination to a woman who had been denied employment benefits on the basis of her "temporary" disability. ${ }^{159}$ This decision has been widely criticized. One commentator observed that the Court's approach in Law v Canada "leaves much to be desired and marks a retreat from the early promise of substantive equality." 160 A second commentator observed that the Law decision is at best, "confusing, unpredictable, overly burdensome and excessively formalistic." $" 161$

Thus despite the expansive definition of substantive equality in Andrews and Eldridge, the future of such decisions in Canada is unclear, at best. For example, a 2010 study found that the Canadian Supreme Court has been reluctant to even hear appeals in cases involving Section 15 of

154 Eldridge, supra note 147.

155 See Rahool Parkash Agarwal, "An Autonomy-Based Approach to Section 15(1) of the Charter" (2006) 12 Rev Const Stud 83 at 92.

156 See e.g. Vande Zande v State of Wisconsin Department of Administration, 44 F (3d) 538 (7th Cir 1995). In Vande Zande, Judge Posner, writing for the Court of Appeal, refused to require an employer to spend $\$ 150$ to install an accessible sink in a workplace kitchen area as an accommodation for an employee, dismissing her claim that it was stigmatizing and discriminatory to require her to use the bathroom sink for activities which the other workers were able to do in the kitchen sink. The humiliation and loss of dignity she endured was never part of the court's cost - benefit analysis.

157 Eaton v Brant (County) Board of Education, [1997] 1 SCR 241 at para 169.

158 Ibid.

159 Law v Canada (Minister of Employment \& Immigration), [1999] 1 SCR 497.

160 Ravi Malhotra, "Has the Charter Made a Difference for People with Disabilities? Reflections and Strategies for the 21st Century” (2012) 58 Sup Ct L Rev 273 at 274.

161 Bruce Ryder \& Taufiq Hashmani, "Managing Charter Equality Rights: The Supreme Court of Canada's Disposition of Leave to Appeal Applications in Section 15 Cases 1989-2010” (2010) 51 Sup Ct L Rev 505 at 518-19. 
the Charter. ${ }^{162}$ Further, one Canadian commentator recently summed up Canadian law with respect to claims for substantive equality for people with disabilities by observing the following:

The present record of disability rights is one of cautious optimism. On the one hand, there has been enormous progress in the Supreme Court's attitude towards Canadians with disabilities. This new social understanding should be lauded and provides strong encouragement for Charter litigation on disability rights in the future. On the other hand, disability law has evidently faced difficulties since the Law decision. ${ }^{163}$

\section{CONCLUSION}

In this Article, I have explored the meaning of equality for people with disabilities under the CRPD, the Americans with Disabilities Act, the Americans with Disabilities Amendments Act, and the Canadian Charter, particularly in the context of employment. I have provided examples of how the CRPD goes beyond traditional notions of formal equality or even equality of opportunities towards a claim for substantive equality for people with disabilities. The CRPD affirms the right of all people, regardless of their labels of permanent or temporary impairments, to equality under law. It also imposes on States Parties the affirmative obligation to remove structural barriers and to make the necessary changes in society to ensure such equality. Although the CRPD will not result in substantive equality overnight in any of the countries that have ratified it, and although the CRPD requires additional action by state actors, NGOs, and selfadvocates in order to be realized, countries, including Canada and the United States now have an opportunity to work towards substantive equality for people with disabilities by enforcing the application of the CRPD's new international norms, particularly in the employment context. Canadian courts have begun to expand the notion of equality that was included in its pre-Charter cases. Now, with the country's ratification of the CRPD, Canadian courts have the means to continue to affirm their commitment to expanding equal rights protection for people with disabilities. The U.S., however, has a longer way to go towards substantive equality for people with disabilities both because of the limits of the Americans with Disabilities Amendments Act as a law focused only on a narrow view of discrimination and because of its failure to ratify the CRPD. Nonetheless, as a signatory to the CRPD, the U.S. also has an opportunity to at least begin to look to the language and interpretation of the CRPD by courts in Canada and elsewhere as a guide for future legislative and judicial action that may further the equality rights of people with disabilities within the United States.

162 Ibid at 517.

163 Marjun Parcasio, “A Progress Report of Disability Rights since the Charter”, online: (2014) LawNow

$<$ lawnow.org/progress-report-disability-rights-since-charter/>. 